\title{
Sociální opora u sociálně exkludovaných romských rodin
}

\author{
David Urban - Alena Kajanová \\ Jihočeská univerzita v Č. Budějovicích, Zdravotně sociální fakulta, Katedra soc. práce, Jírovcova 24, Č. Budějovice, 37004
}

Do redakce doručeno 6. února 2014; k publikaci přijato 20. května 2014

\section{SOCIAL SUPPORT TO SOCIALLY EXCLUDED ROMANY FAMILIES}

\begin{abstract}
The article deals with the topic of social support to socially excluded Romany families. The topic was processed based on the data acquired within field research in selected Romany families living in excluded localities of South Bohemian Region. The data were processed in Atlas.ti Program. The results have shown that primarily material form of social support is both drawn and provided, and its main source - both real and anticipated - is the family in the place of residence. Support is not expected from non-Romany institutions, but it is really used in different forms, including information support. The sources of support change with regard to generation; younger generation shows reduced intergenerational readiness to help.
\end{abstract}

KEY WORDS Romany minority; Romany family; social support; social exclusion; institution

ABSTRAKT Článek se věnuje tématu sociální opory u exkludovaných romských rodin. Téma bylo zpracováno na základě dat získaných v rámci terénního výzkumu ve vybraných romských rodinách žijících v exkludovaných lokalitách Jihočeského kraje. Data byla zpracována v programu Atlas.ti 7. Z výsledků vyplynulo, že je čerpána i poskytována především materiální forma sociální opory, kde jejím hlavním zdrojem - at již reálným či anticipovaným, je rodina v místě bydliště. Od majoritních institucí (majoritními institucemi rozumíme ty organizace, jejichž primární cílovou skupinu netvoří Romové) opora očekávána není, je ale reálně využívána v různých podobách, včetně opory informační. Zdroje opory se mění s ohledem na generaci, kde v mladší generaci dochází k snižování mezigenerační ochoty pomoci.

KLÍČOVÁ SLOVA romská minorita; romská rodina; sociální opora; sociální exkluze; instituce

\section{ÚVOD}

Článek se zabývá tématem sociální opory u sociálně exkludovaných romských rodin. Teoretická východiska popisují význam sociální opory především ve vztahu k romské rodině, která představuje její nejvýznamnější zdroj. Data pro výzkumnou část byla získána $\mathrm{v}$ rámci terénního výzkumu $\mathrm{v}$ romských rodinách žijících $\mathrm{v}$ sociálně vyloučených lokalitách a kódována v programu Atlas.ti 7. Po vytvoření seznamu kódů se přešlo $\mathrm{k}$ systematické kategorizaci dat. Kódy vzniklé z otevřeného kódování byly následně seskupeny do kategorií a podkategorií. Následně byly jednotlivé kategorie odpovědí uspořádány do schémat (network). Výzkumný soubor tvořilo 15 informantů, Romů a Romek, kteří žijí v sociálně vyloučených lokalitách.

Článek je jedním z výstupů projektu „Sociální determinanty zdraví u vybraných cílových skupin” č. SDZ2012_002 (hlavní řešitelka doc. Mgr. et Mgr. Jitka Vacková, Ph.D.). Projekt byl podpořen ze zdrojů Jihočeské univerzity v Českých Budějovicích, Zdravotně sociální fakulty.

\section{VYMEZENÍ SITUACE EXKLUDOVANÝCH ROMSKÝCH RODIN V ČESKÉ REPUBLICE}

Romská minorita je popisována jako jedna $\mathrm{z}$ nejpočetnějších a zároveň nejzranitelnějších minorit $\mathrm{v}$ Evropě. $\mathrm{V}$ České republice žije několik subetnických skupin Romů a Romek, jejichž celkový počet se odhaduje na 220 až 250 tisíc. (Davidová a kol. 2010, 17). V posledních letech se však projevuje pokles počtu osob, které se otevřeně hlásí k romské národnosti. Při sčítání lidu se ke své národnosti přihlásilo v roce 199133486 
osob, v roce 2001 již jen 11716 osob a v roce 2011 dokonce pouhých 5135 osob (Sč́tání lidu, domů a bytů 2011).

Stratifikační struktura romského obyvatelstva je různorodá. Podle Gabalovy zprávy je z uvedeného počtu Romů a Romek v ČR asi 80 tisíc označováno za sociálně vyloučené. „Jako sociální vyloučení lze označit proces, $v$ jehož rámci je jedinci, skupině jedinců či komunitě výrazně znesnadňován či zcela zamezován př́stup ke zdrojům, pozicím a př́ležitostem, které umožňují zapojení do sociálních, ekonomických a politických aktivit majoritní společnosti“ (Analýza sociálně vyloučených romských lokalit a absorpční kapacity subjektů působících v této oblasti 2006, 9). Sociální exkluze je bezesporu jedním z nejpalčivějších celoevropských sociálních problémů současnosti. V Evropě je více než 120 milionů osob ohroženo chudobou či sociální exkluzí a boj proti ní patří mezi hlavní priority (European Commision 2014).

Mezi skupiny ohrožené sociálním vyloučením patří právě především romská menšina, kdy její zástupci tvoří minimálně $80 \%$ obyvatel exkludovaných lokalit. Jako sociálně vyloučená romská lokalita je definován $\mathrm{v}$ Analýze sociálně vyloučených romských lokalit a absorpční kapacity subjektů působících v této oblasti $(2006,10)$ prostor obývaný skupinou, jejíž členové se sami považují za Romy a/nebo jsou za Romy označováni svým okolím, a jsou sociálně vyloučeni. „K tomu, aby byla lokalita vnímána jako romská, přitom není vůbec nutné, aby Romové $\mathrm{v}$ dané lokalitě tvořili statistickou většinu. Existují pochopitelně také sociálně vyloučené lokality, v nichž je podíl Romů malý, či kde Romové vủbec nežiji“ (Analýza sociálně vyloučených romských lokalit a absorpční kapacity subjektů působících v této oblasti 2006, 10).

Sociálně vyloučené lokality jsou obecně spojeny s vysokou mírou kriminality, nedostupností zdrojů a príležitostí, omezenými sociálními kontakty a také se zvýšeným výskytem sociálně patologických jevů (Strategy for Combating Social Exclusion for the period 2011-2015 2011). Jedním z průvodních jevů prohlubování sociálního vyloučení a "ghettoizace“ vyloučených lokalit je nárůst nezákonného a protizákonného jednání jak uvnitř vyloučených lokalit, tak v jejich okolí, kam se nezákonné aktivity emitují, expandují a zasahují populaci mimo vyloučenou enklávu (Gabal, Višek 2010, 47).

\section{SOCIÁLNÍ OPORA A ROMSKÉ RODINY}

Sociální opora představuje již tř̌i dekády jedno z hlavních témat zájmu sociální psychologie (Sarason, Sarason \& Gurung, 1997). Jedná se o široký pojem zahrnující různé podpůrné systémy sociálního prostředí. Shumaker a Brownell (1984, 13) popisují sociální oporu jako výměnu zdrojů mezi dvěma a více lidmi, která vede ke zvýšení blahobytu př́ijemce. Albrecht a Adelman $(1987,19)$ definovali sociální oporu jako verbální a neverbální komunikaci mezi př́jemci a poskytovateli, která snižuje nejistotu ve vztahu $\mathrm{k}$ sobě, $\mathrm{k}$ druhým, nebo ve vztazích a funkcích a přispívá (vede) k posílení vnímání osobní kontroly v průběhu životní zkušenosti. Gottlieb (2000, 28) vymezuje sociální oporu šíreji, jako proces interakcí ve vztahu, který zlepšuje zvládání zátěžových situací, sounáležitost a kompetence prostřednictvím skutečné nebo vnímané výměně fyzických či psychologických prostředků. Thoits $(2010,46)$ popisuje sociální oporu jako emocionální, informační, nebo praktickou pomoc od významných druhých, jako jsou členové rodiny, přátelé či kolegové, přičemž podpora může být jak reálně přiijímána, tak i potencionálně vnímaná. $\mathrm{Z}$ českých zdrojů můžeme uvést např. tyto definice sociální opory. Dle Kebzy a Šolcové $(1999,20)$ je sociální opora jakýsi sociální fond, ze kterého lze čerpat $\mathrm{v}$ př́padě potřeby, také systém sociálních vztahů, jejichž prostřednictvím se člověku dostává pomoci při snaze dostát nárokủm a dosáhnout cílů. Zdroje sociální opory jsou součástí systému sociálních vztahů jedince. „Sociální oporou v širším slova smyslu se rozumí pomoc, která je poskytována druhými lidmi člověku, který se nachází v zátěžové situaci. Obecně jde o činnost, která člověku v tísni jeho zátěžovou situaci určitým způsobem ulehčuje“ (Kř̀ivohlavý 2001, 94). „Sociální opora nám pomáhá zvládat životní těžkosti, a to především tehdy, pokud člověk onemocní, dostane se do životní krize, utrpí úraz, stojí před vážným rozhodnutím, když mu někdo blízký zemře apod." (Křivohlavý 2001,98 ).

Rozsah sociální opory můžeme rozlišit do třech oblastí: mikro, mezo a makro úrovně. (Gottlieb 1985). Makroúroveň sociální opory je oblastí zabývající se celospolečenskou formou pomoci potřebným, mezoúroveň představuje oporu, kterou poskytuje sociální skupina svému členovi, pomoci by však měla i osobám v nouzi, kteří nejsou členy skupiny. Mikroúroveň sociální opory je oporou v rámci dyády, tzn. dvojice lidí, jež jsou si nejbližší (např. pomoc matky dítěti, nebo vzájemná pomoc manželů) (Křivohlavý 2001, 95).

Existuje několik modelů, které vymezují typy sociální podpory. House (1981) rozlišuje čtyři typy podpory. Emocionální opora je spojena se sdílením životních zkušeností. Jedná se o poskytování empatie, lásky, důvěry a péče. Instrumentální opora zahrnuje poskytování hmotné pomoci a služeb osobám v nouzi. Je poskytována blízkými práteli, kolegy a sousedy. Informační opora zahrnuje poskytování poradenství, návrhy a informace, které člověk může použít $\mathrm{k}$ řešení problémů. Poslední typ opory zahrnuje poskytování informací, které jsou užitečné pro účely sebehodnocení: konstruktivní zpětnou vazbu, potvrzení a sociální srovnání. Sociální opora je jednou z důležitých funkcí sociálních vztahů a je realizována prostřednictvím sociálních sítí (Glanz et al. 2002). Dle Křivohlavého (2001) jsou zdroje sociální opory obsaženy v šesti hlavních kategoriích: rodina, blízcí přátelé, sousedé, spolupracovníci, komunita a profesionálové.

V odborné literatuře se setkáváme především s kladným hodnocením sociální opory. Až v posledních letech se objevují práce, které se zabývají „odvrácenou tváríi“ sociální opory Kebza 2005, 164). Stinné stránky sociální opory zaznamenáváme i v romských rodinách.

Rizikové faktory účinku sociální opory můžeme rozdělit do dvou skupin:

1. Záporně laděné interpersonální vztahy

Do této skupiny patří všechny negativní sociální interakce - 


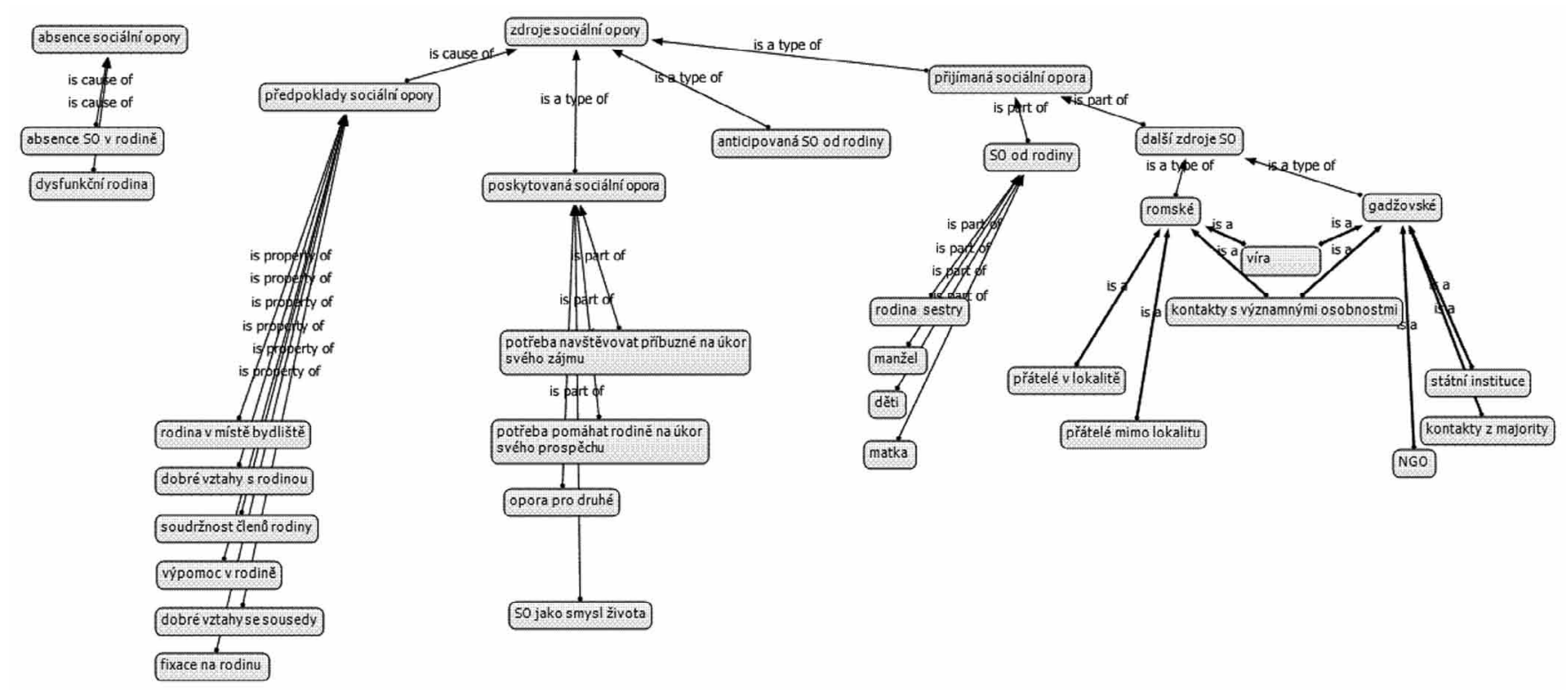

Obr. 1. Sociální opora u romských rodin (sítě) Zdroj: Vlastní výzkum

podceňování partnera, nedostatek zájmu o problém druhé osoby, přetvářka, lhaní.

2. Záporné důsledky původně pozitivních vztahů

Interpersonální vztahy mohou být přínosem i ztrátou. Mezi interpersonální interakce s negativním dopadem patří například konflikt, odmítnutí, nesouhlas, přemrštěné nároky a útočné aktivity (Kebza 2005, 165). Důsledkem toho mohou být pocity viny, úzkosti, závislosti, ztráta soběstačnosti, poničené sebehodnocení, ztráta kontroly nad událostmi, připuštění neschopnosti řešit samostatně své problémy (Kebza 2005, 166).

S negativním působením sociální opory se setkáme i u Romů. Romská rodina vychovává své jedince tak, aby byli na rodině materiálně i psychicky závislí a brání jejich individuálnímu rozvoji. Rodinné pouto bývá velmi silné a může tak i být jednou z překážek integrace do majoritní populace (Vágnerová 2004, 679). Tudíž Rom potřebuje podporu od své rodiny či aktuálního sociálního prostředí (sítě) neustále a nepřetržitě (Sekyt 2004, 207).

Nukleární rodiny jsou u Romů mnohem početnější, než u populace majoritní (Budilová, Jakoubek 2004, 35-36). Mateřství připisují velký význam (Budilová, Jakoubek 2007, 33). Romské děti bývají vychovávány volně, nedirektivně a musí plnit minimum povinností (Vágnerová 2008, 686). Raná péče o dítě je v kompetenci matky. Tento většinou velmi intenzivní vztah je základní pro vytvoření pocitu soudržnosti s celou rodinou (Sekyt 2004, 201). U Romů se sociální opora vyznačuje soudržností, solidaritou, sounáležitostí členů rodiny, př́buzenskou blízkostí a intenzivními kontakty (Davidová 2004, 112). Své problémy řeší společně, $s$ tímto se mohou profesionálové setkat např. na úřadech, tak př̀i poskytování péče ve zdravotnických zařízeních.

\section{METODIKA}

Data byla sbírána technikou polořízených rozhovorů s romskými informátory - ti se sami za Romy považovali. Rozhovory byly vedeny v českém jazyce. ${ }^{1}$ Osloveni byli respondenti z vybraných sociálně vyloučených lokalit v Táboře, Písku a Českých Budějovicích. Tyto sociálně vyloučené lokality, uváděné Analýzou (Analýza sociálně vyloučených romských lokalit a absorpční kapacity subjektů působících v této oblasti, 2006), byly vybrány na základě dostupnosti - zde byl zajištěn př́stup do sociálně vyloučené lokality $\mathrm{k}$ informátorům prostřednictvím sociálních pracovníků/ic, kteří v lokalitě působí. Celkem byl rozhovor veden s 15 informátory.

Rozhovory byly se souhlasem informátorů nahrávány na diktafon a poté doslovně transkribovány.

Vyhodnocování dat probíhalo za pomoci Atlasu.ti 7 tak, že $\mathrm{v}$ rozhovorech byly označovány výpovědi respondentů, vztahující se $\mathrm{k}$ cílům výzkumu, které byly následně kódovány. Pokud se v textu objevila další výpověd, vztahující se k již existující kategorii, byla $\mathrm{k}$ této kategorii přiřazena, v opačném př́padě byla sestavena kategorie nová.

Následně byly jednotlivé kategorie setříděny do rodin, dle obsahové významnosti. Takto jsme vytvořili 4 kategorie: předpoklady sociální opory, poskytovaná sociální opora, anticipovaná (resp. očekávaná) sociální opora od rodiny a prijímaná sociální opora a dle těchto kategorií následně data prezentujeme a doplňujeme o přímé výpovědi respondentů.

1 Rozhovory byly vedeny v českém jazyce $\mathrm{z}$ důvodu neznalosti romštiny na straně tazatelů i informantů. 


\section{VÝSLEDKY VÝZKUMNÉHO ŠETŘENÍ}

\section{Zdroje sociální opory}

Do oblasti zdrojů sociální opory je možné zahrnout následující čtyři kategorie: předpoklady sociální opory, poskytovaná sociální opora, anticipovaná (resp. očekávaná) sociální opora od rodiny a přijímaná sociální opora.

\section{Předpoklady sociální opory}

Základním předpokladem pro získávání sociální opory byla uváděná přítomnost rodiny v místě bydliště, přičemž se nutně nemuselo jednat o soužití rodiny $\mathrm{v}$ jednom bytě, či domě. Postačující byla pouhá dostupnost rodiny v blízkém okolí. Dalšími důležitými předpoklady sociální opory byly uváděny dobré vztahy $\mathrm{v}$ rodině a soudružnost členů v rodině, prričemž tyto faktory byly primárně zmiňovány starší generací (do níž patřily osoby nad 50 let), která hovořila o pevných vztazích, které $\mathrm{v}$ době jejich mládí $\mathrm{v}$ rodinách byly, zároveň zmiňovali, že se tato soudružnost $\mathrm{v}$ současných romských rodinách, oproti dřívějším časům, vytrácí.

„Ale když ještě žila babička i dědeček, to si ještě pamatuji i já, tak do těch dětí vložili strašnou lásku. A i tu úctu v sobě, aby si udrželi jeden druhýho. A v tom je to dobrý, aby si každej udržel jeden druhýho, v každej situaci jako. " (žena, 63 let)

Potřeba dobrého vztahu $\mathrm{v}$ rodině u některých respondentů „přerůstá“ až ve fixaci na rodinu, která však není vnímána negativně, spíše naopak je zdrojem pomoci a opory.

„Já jsem jako bydlela v Protivíně, ale každej víkend, furt jsem byla tady (Písek, pozn. autorů), jako rodina je všechno. Já si jako myslím, že člověk je až závislej na tu rodinu. A já jsem strašně fixovaná na tu rodinu. " (žena, 41 let)

Nezanedbatelným důsledkem sociální opory je také vzájemná výpomoc členů v rodině. Jednat se může jak o materiální výpomoc - finanční prostředky, potraviny, oblečení aj., tak i o výpomoc nemateriální ve formě hlídání, pomoci s úklidem, aj.

„Ale stane se jako já nemám tohle, tohle. Tak si jako pomůžeme. Třeba ona mi řekne, hele co jsi dneska dělala. No a já dělala polívku a guláš a kolínka. No a vím, že třeba maminka na paprice nejí, že to nemůže. Tak třeba mi přinese pro maminku $v$ kastrůlku něco a je to. "(žena, 41 let)

Rodina byla tedy uváděna jako jeden ze základních předpokladů pro sociální oporu, nikoliv však jako předpoklad jediný. Dalším důležitým faktorem byl zmiňován i dobrý vztah se sousedy.

\section{Poskytovaná sociální opora}

Předpokladem pro to, aby byla opora přijímána, musí být také někým poskytována. $Z$ výpovědí námi oslovených ko- munikačních partnerů vyvstávají tři oblasti, vztahující se k poskytování sociální opory: a) potřeba navštěvovat příbuzné na úkor svého zájmu, b) potřeba pomáhat rodině na úkor svého prospěchu, c) pojetí SO jako smyslu života.

a) Potřeba navštěvovat příbuzné na úkor svého zájmu

Komunikační partneři uváděli, že v některých ohledech je potřeba upřednostnit zájmy rodiny před zájmem svým. V opačném př́padě by mohlo dojít $\mathrm{k}$ nabourání dobrých vztahů. Tato situace však byla i přes zjevný negativní dopad pro jedince (nemám čas udělat si svou práci) hodnocena $\mathrm{v}$ konečném důsledku pozitivně, nebot rodina byla vnímána jako důležitý prvek v životě, a to jak v současnosti, tak i ve vyhlídce na budoucnost (až já budu potřebovat, budu taky rád, když za mnou někdo přijde a popovídá si se mnou).

„Protože já když prijidu domu, tak tady nemůžu dělat ani tu svou práci. Protože já když přijdu domu, tak všichni jsou štastní, že si doma a všechny musíš obejít a pak si na každý návštěvě dvě tři hodiny...jinak se na tebe urazí, že už nechodiš, že už si takovej..."(muž, 24 let)

b) Potřeba pomáhat rodině na úkor svého prospěchu

Dalším pomyslným stupněm upřednostňování lze vnímat potřebu pomáhat rodině na úkor svého prospěchu, nejčastěji tato potřeba byla zmiňována ve vztahu $\mathrm{k}$ materiálním potřebám, tzn. peněz, či stravování. Rodina, která subjektivně hodnotila svou finanční situaci negativně

(tzn. neměla dostatek finančních prostředků na uspokojování svých potřeb), byla ochotna poskytovat stravu i vzdálenějším příbuzným, jejichž situace byla ještě nepříznivější. Toto jednání vedlo $\mathrm{k}$ dalším finančním problémům zmiňované první rodiny (následně nezbývaly finanční prostř̌edky např. na nájem, atd.).

„No samožrejmě, se tu stravujou, prostě všechno. Takže já když vařim, tak mi to třeba nebudete věrit, ale já dělam, když třeba dělam špagety, s milánskou, tak dávam troje špageti vařit. Naberu z toho a nejni. Jo deset lidí. Ted' přijde dalši brácha, ségra, nají se tu třeba šestnáct, sedmnáct lidí třeba. To už je jako nezvladatelný. Oni jsou už u mě skoro rok a jako tři lidi navíc, je to prostě znát. Je to o penězích, o všom to je, o jídle..." (žena, 21 let)

\section{Sociální opora jako smysl života}

Být oporou pro jiné, pomáhat členům rodiny - to jsou nejčastější výroky informantů z řad starší generace. Ti považují za důležité být zde pro své děti a vnoučata, pomáhat jim a podporovat je. $\mathrm{V}$ celé řadě př́padů byl tento důvod jmenován jako nejdůležitější smysl života.

„Jo moje děti a moje vnoučata. je pro koho žít. Ale my jsme takhle všechny sestry. “(žena, 63 let)

T: A kde berete tu sílu...?

R: Ta musí být vevnitř. A říct si i přes to všechno, já chci žít. Protože já mám pro koho žít." (žena, 54 let) 


\section{Anticipovaná sociální opora}

Informanti nejčastěji očekávají, $\mathrm{v}$ případě potřeby, pomoc ze strany své rodiny. Ze strany města, státu a ani sousedů není př́padná pomoc očekávaná, ačkoliv ale je přijímaná (např. ve formě sociálních dávek).

„Tak určitě rodina. Jako kdybych dopad tak, že bych nemél kam jit, tak určitě pres rodinu bych to ř rěil. Ale jako stát, nebo okres, to ne..." (muž, 34 let)

\section{Přijímaná sociální opora}

Nejobsáhlejší kategorií je oblast přijímané sociální opory, přičemž výpovědi v této kategorii můžeme rozdělit do dvou základních podkategorií, za a) sociální opora od rodiny, a za b) další zdroje sociální opory.

\section{a) Sociální opora od rodiny}

V této kategorii byly vyjmenováváni členové rodiny, kteř́ informantům nejčastěji sociální oporu poskytují. Za nejdůležitější zdroj sociální opory jsou považovány děti a matka.

„T: A takže co vám pomohlo přestát tuhle situaci, jak jste to zvládala, nebo pomocí čeho

R: No, ono jako takhle, já jsem slabší povahy. Ale ono maminka, mi strašně dávala sílu, protože ona i když je takhle nemocná, tak ona něco, ona vám dává sílu, ona umí strašně ty lidi podržet." (žena, 41 let)

„Když umřel můj brácha, tak mě taky držely dèti, nebejt těch dètí, tak bych to snad nezvládla, protože jsem na ně byla hodně zafixovaná“ (žena, 21 let)

Dalším nejčastěji zmiňovaným zdrojem sociální opory byl jmenován partner, př́padně pak sourozenci.

\section{b) Další zdroje sociální opory}

Oblast „dalších zdrojů sociální opory“ lze rozdělit na dvě základní oblasti, a to oblast romských zdrojů a oblast zdrojů majoritních.

Mezi romské zdroje, coby další zdroje SO, byly jmenováni jak přátelé $v$ lokalitě, tak přátelé mimo lokalitu, kteří $v$ př́ípadě potřeby mohou pomoci:

„R: No tak tady....tady jako jsou to Romové no. Některý si žijou líp, některý hưr̆ no, tak když něco dojde, tak jako přijdou, hele pane XY pomož, piojč, dej nám, tak má to výhodu.

T: Tak si i takhle pomáháte.

R: Jo, tak jako taky no. Tak když člověk vidíže jako má děti a že sotva vyjde taky no, tak mu daj. Ale taky jsou tady ty ženský, $k d y z ̌$ jsou sami a když berou di̊chod, tak jdou dolu a prohrajou, tak pak nemaj co jíst, no." (muž, 58 let)

Z výše uvedeného výroku je zajímavým momentem ta skutečnost, že vzájemná pomoc má své meze - tedy někomu je pomoc poskytnuta (napr. matka s dítětem), jinému naopak poskytnuta není (např. zmiňovaná hráčka na automatech). Je tedy patrná existence hranice vzájemné pomoci, „kdy/komu ještě pomohu a kdy/komu již nikoliv.

„R: Tak problém, problém. Záleží co je za problém. Tak když je možná nějaká vzájemná pomoc, tak určitě, to jo. Ale záleží co to je.

T: Tak třeba když nejsou peníze...

R: Jo jasný, tak si pomůžem tak normálně jak to funguje mezi těmi práteli, kamarády a tak, to asi funguje všude." (muž, 58 let)

Mezi další důležité romské zdroje sociální opory se řadí „významné, či jinak důležité osobnosti“, kteří mohou pomoci (at již prrímo, či tím, že naučí novým poznatkům, zpřístupní další možnosti). Do určité míry se může také jednat o sociální prestiž - kontakt s významnou osobou:

„...tak no viš a když sem třeba, když spolupracuješ s Idou ${ }^{2}$, tak ona tě to hodně posune dál." (muž, 24 let)

Nezanedbatelným zdrojem sociální opory byla uváděná také víra v Boha:

„A $z$ čeho bereš sílu, co tě dává sílu...

$R$ : Já tak nevím, tak určitě tak asi si říkám, že Bưh chce, že co máš dělat, tak to asi máš dělat. Tak jako že asi hodně, jako hodně...brát odkud. Když se třeba, když jako ted'nechci říct, že když chodím do kostela, tak že mám víc síly než ostatní, ale ono to fakt pomáhá, když přijdeš na mši, a jdeš ke svatýmu přijímání. A ted' tu hodinu máš jako třeba pro sebe." (muž, 24 let)

Do oblasti majoritních zdrojů sociální opory lze pak zařadit a) nestátní neziskové organizace (charita, občanské poradny aj.), b) kontakt s osobami $\mathrm{z}$ majoritní populace, které mohli být opět otázkou sociální prestiže mezi Romy:

Pro nás poměrně zajímavým zjištěním byl fakt, že ani jeden z informantů nezmínil pomoc ze strany státu a úřadů, byt se jednalo o osoby, kteří sami, př́ípadně další členové jejich rodiny, byli poživateli různých sociálních dávek a podpor. I na prrímý dotaz, zda získávají, či očekávají pomoc od těchto institucí informanti uváděli zápornou odpověd'.

\section{ZÁVĚREM}

Sociální opora u Romů a sociálně exludovaných není v českém ani zahraničním prostředí zatím dostatečně reflektována. Z výsledků našeho výzkumného šetření vyplývá, že nejvýznamnější činitel anticipované i realizované sociální opory pro exkludované Romy a Romky představuje rodina. Je možné, že by tento závěr platil i pro majoritní společnost, avšak ta nebyla předmětem našeho výzkumného záměru. Získaná

2 Ida Kelarová je romská zpěvačka. (pozn. autorů) 
opora je především materiálního a finančního charakteru, př́padně se jedná o pomoc $\mathrm{v}$ domácnosti a s hlídáním dětí. K podobným výsledkům došly Crondahl and Eklund (2012), které se zaměřily na vnímání kvality života a osobní pohody u romských adolescentů ve Švédsku. V nepříznivých sociálních situacích vyhledávali jejich respondenti pomoc rodiny a přátel. Získávaná sociální opora však v jejich př́ípadě byla především emocionálního charakteru a v komplikovaném období přinášela př́ijemcům pozitivní myšlenky a náhled na život.

Kolarcik et al. (2012) komparovali ukazatele psychosociální pohody romských a neromských adolescentů. Z výsledků vyplynulo, že romští adolescenti vykazují větší míru beznaděje, ale jsou se svým životem spokojenější a dostávají vyšší míru sociální opory od svých rodičů. Naše data ukázala, že v této oblasti dochází k určité generační změně, kdy mladší generace sice oporu ze strany svých rodin očekávají, avšak již v takové míře nenabízejí. To může být spojeno s obecnými změnami $\mathrm{v}$ romské rodině, $\mathrm{kdy}$ dochází $\mathrm{k}$ proměnám rolí, vytrácení se úcty ke starším, atp. (srov. Davidová a kol. 2011). Pomoc rovněž není poskytována automaticky, musí být splněny podmínky funkčnosti a soudržnosti rodiny a v neposlední řadě též blízkost bydliště.

Dalším zdrojem různých forem sociální opory jsou přátelé vně i mimo lokalitu, především ti, kteří představují jakousi elitní skupinu a tedy i disponují potřebnými zdroji.

Finanční a informační sociální oporu získávají informanti a informantky ze strany institucionálních státních a NGO zařízení v podobě sociálních dávek a sociálních služeb. Zde je zajímavé, že romské rodiny pomoc z těchto zdrojů neočekávají, ačkoli ji reálně čerpají.

\section{LITERATURA}

Analýza sociálně vyloučených romských lokalit a absorpční kapacity subjektů působících v této oblasti. Praha: Gabal Analysys and Consulting, 2006.

Albrecht, T. L., Adelman M. B. (1987): Communicating social support: A theoretical perspective. In: Albrecht, T. L., Adelman M. B., eds., Communicating social support, Newbury Park, CA: Sage, 18-39.

Barnes, J.A. (1954): Class and Committees in a Norwegian Island Parish. Human Relations, 7, 39-58.

Berkman, L.F., Glass, T., Brisette, I. \& Seeman, T.E. (2000): From Social Integration to Health: Durkheim in the New Millenium, Social Science and Medicine, 51, 843-857.

Budilová, L., Jakoubek, M. (2004): Příbuzenství v romské osadě. In: Jakoubek, M., Hirt, T., Romové: kulturologické etudy, Plzeň: Aleš Čeněk, 9-65.

Budilová, L., Jakoubek, M. (2007): Cikánská rodina a př́ibuzenství. Ústí nad Labem: Dryada.

Crondahl, K., Eklund, L. (2012): Perceptions on health, well-being and quality of life of Balkan Roma adolescents in West Sweden. Romani Studies, 22 (2), 153-174.

Davidová, E. (2004): Romano drom - Cesty Romů 1945-1990. Olomouc: Univerzita Palackého.

Davidová, E. et al. (2010): Kvalita života a sociální determinanty zdraví u Romů v České a Slovenské republice. Praha: Triton.

European Commision. [online]. [cit. 2014-01-01]. Dostupné z: http:// ec.europa.eu/social/main.jsp?catId=751.

Gabal I., Višek, P. a kol. (2010): Východiska Strategie boje proti sociálnímu vyloučení: Východiska pro formulaci a implementaci politiky začleňo- vání obyvatel vyloučených lokalit do české společnosti a její sociální a ekonomické struktury. Praha: Vláda ČR. (online). http://www.gac.cz/ userfiles/File/nase_prace_vystupy/GAC_Strategie_soc_vylouceni.pdf.

Glanz, K., Rimer, B.K. \& Lewis, F.M. (2002): Health Behavior and Health Education. Theory, Research and Practice. San Fransisco: Wiley \& Sons.

Gottlieb, B. H. (1985): Social networks and social support: an overview of research, practice and policy implications. Health Education Quarterly, 12(1), 5-22.

Gottlieb, B. H (2000): Selecting and planning support interventions. In: S. Cohen, L. Underwood, B. Gottlieb, eds., Social suport measurement and intervention, London: Oxford University Press, 195-220.

Hogan, B.; Linden, W., \& Najarian, B. (2002): Social support interventions: do they work?. Clinical Psychology Review, 22 (3), 381-440.

House, J. S. (1981): Work Stress and Social Support. Reading, Mass: Addison-Wesley.

Kebza, V., Šolcová, I. (1999): Sociální opora jako významný protektivní faktor. Československá psychologie, 41 (1), 19-35.

Kebza, V. (2005): Psychosociální determinanty zdraví. Praha: Academia.

Křivohlavý, J. (2001): Psychologie zdraví. Praha : Portál.

Kolarcik P. (2012): Social support, hopelessness and life satisfaction among Roma and non-Roma adolescents in Slovakia. International Journal Of Public Health, 57 (6), 905-913.

Sarason, B. R., Sarason, I. G. \& Gurung, R. A. R. (1997): Close personal relationships and health outcomes: A key to the role of social support. In: S. W. Duck, ed., Handbook of personal relationships: Theory, research and interventions, Chichester, UK: Wiley, 547-573

Shumaker, S. A., Brownell, A. (1984). Toward a Theory of Social Support: Closing Conceptual Gaps. Journal of Social Issues, 4 (4), 11-36.

Strategy for Combating Social Exclusion for the period 2011-2015 (2011): Agency for Social Inclusion in Roma Localities. (online). http://www. socialni-zaclenovani.cz/dokumenty/strategie-boje-proti-socialnimu-vylouceni/strategy-for-combating-social-exclusion-for-the-period-2011-2015/details.

Thoits, P. A. (1982): Conceptual, Methodological, and Theoretical Problems in Studying Social Support as a Buffer Against Life Stress. Journal of Health and Social Behavior, 23(2), 145-159.

Thoits P. A. (2010): Stress and health: major findings and policy implications. Journal of Health and Social Behavior, 51(Suppl.), 41-53.

Sekyt, V. (2004): Romské tradice a jejich konfrontace se současností (Romství jako znevýhodňující faktor). In: Jakoubek, M., Hirt, T., Romové: kulturologické etudy, Plzeň: Aleš Čeněk.

Sčítání lidu, domů a bytů 2011 - Česká republika (2011): Český statistický úrad. (online). http://notes2.czso.cz/csu/2012edicniplan.nsf/p/01000-12. Vágnerová, M. (2008): Psychopatologie pro pomáhající profese. Praha: Portál.

\section{AUTOŘI}

PhDr. David Urban, Ph.D. je vedoucím katedry sociální práce na Zdravotně sociální fakultě Jihočeské univerzity v Českých Budějovicích. Předmětem jeho zájmu je sociální práce s romskou minoritou v sociálně vyloučených lokalitách a teorie a metody sociální práce.

Kontakt: David Urban, Jihočeská univerzita v Č. Budějovicích, Zdravotně sociální fakulta, Katedra soc. práce, Jírovcova 24 , Č. Budějovice, 370 04, email: durban@zsf.jcu.cz

PhDr. Alena Kajanová, Ph.D. je odbornou asistentkou na katedře sociální práce Jihočeské univerzity v Č. Budějovicích, Zdravotně sociální fakulty. Věnuje se tématu minorit a marginalizovaných skupin.

Kontakt: Alena Kajanová, Jihočeská univerzita v Č. Budějovicích, Zdravotně sociální fakulta, Katedra soc. práce, Jírovcova 24, Č. Budějovice, 370 04, email: kajanova@zsf.jcu.cz, tel.:732 155818 